\title{
Comparison of Serum Vitamin D and Calcium Lev- els Between Children with Longer Than Normal Eruption Time of First Deciduous Tooth and Control Group
}

\author{
Akram Noori Nezhad ${ }^{1}$, Katayoun Salem ${ }^{2}$,Mehrdad Zamanian², \\ Saba Aghaei $(D) * 3$ \\ ${ }^{1}$ Private Practice, Tehran, Iran. \\ ${ }^{2}$ Pediatric Dentistry Dept, Faculty of Dentistry,Tehran Medical Sciences,Islamic Azad University, Tehran, \\ Iran. \\ ${ }^{3}$ Pediatric Dentistry Dept, Faculty of Dentistry,Tehran Medical Sciences, Islamic Azad University, Tehran, \\ Iran.
}

\section{ARTICLE INFO}

Article History

Received:May 2021

Accepted: Apr 2021

ePublished: June 2021

Corresponding author:

Saba Aghaei,Pediatric Dentistry Dept, Faculty of Dentistry,Tehran Medical Sciences, Islamic Azad University, Tehran, Iran , saba_aghaee@yahoo.com

\begin{abstract}
Background and Aim: Tooth eruption is a multifaceted physiological process, which can be delayed by factors such as malnutrition. This study aimed to compare the serum levels of vitamin D and calcium in infants with a longer than normal eruption time of the first deciduous tooth with the control group (normal eruption). Materials and Methods: In this case-control study, serum levels of vitamin D in 61 children with a mean age of normal dental eruption in Iranian children ( 8 months and less) were compared with 61 children with eruption age of more than 8 months. The children were matched in terms of age, sex, place of birth and residence, age of birth, birth weight, and other eruption-related items. Student's t-test, analysis of variance (ANOVA), and chi-square test were used for statistical analysis.

Results:The first erupted tooth in all infants was the mandibular incisor. The mean serum level of vitamin D was $38.1 \pm 24.1 \mathrm{ng} / \mathrm{ml}$ in infants with eruption age of 8 months or less and $40.0 \pm 21.5 \mathrm{ng} / \mathrm{ml}$ in the group of eruption age over 8 months $(\mathrm{P}=0.63)$. Serum calcium level was $10.03 \pm 0.55 \mathrm{mg} / \mathrm{dl}$ in the first group and $9.92 \pm 0.57 \mathrm{mg} / \mathrm{dl}$ in the second group $(\mathrm{P}=0.28)$. There was no significant relationship between gender, maternal education, $\mathrm{A}+\mathrm{D}$ supplementation, infant nutrition (breast milk, formula, and combination), and different levels of vitamin $\mathrm{D}$ (deficient, inadequate, adequate, and toxic) with the average age of eruption of the first deciduous tooth $(\mathrm{P}>0.05)$.

Conclusion: It seems that serum vitamin $\mathrm{D}$ and calcium levels in this age group do not affect the eruption time of deciduous teeth.
\end{abstract}

\section{J Res Dent Maxillofac Sci 2021;6(3):25-30.}

Keywords: Eruption, Deciduous Tooth, Serum, Vitamin D, Calcium

\section{Introduction}

Tooth eruption is one of the most important stages of a child's development, and the late eruption of deciduous teeth is one of the concerns of parents that can lead to the cost of specialized examinations and referral to various physicians..$^{(1)}$ Eruption time of deciduous teeth is a multi-causal phenomenon that is affected with inheritance by more than $70 \%$. The eruption of deciduous teeth, in addition to hereditary factors that appear as differences in eruption with sex and ethnicity, can be affected by environmental factors such as infant nutrition..$^{(2-4)}$
Vitamin D is one of the essential micronutrients that its deficiency in children can lead to nutritional rickets. ${ }^{(5-7)}$

The effect of malnutrition on the eruption of deciduous and permanent teeth has been discussed in several studies. ${ }^{(8,9)}$

One of the most common malnutrition problems in the world is vitamin D deficiency, which in many cases goes undiagnosed. Vitamin D is made up of two prerequisites for vitamin D3, which is made from 7-dehydrocholesterol in the skin, or when taken with food or a vitamin D2 supplement (ergocalciferol), and is converted to 
$25(\mathrm{OH}) \mathrm{D}$ in the liver.

The level of this vitamin is assessed by measuring serum levels of $25(\mathrm{OH}) \mathrm{D}$ and has a halflife of 14 to 20 days. $^{(10-12)}$ In children with malnutrition, vitamin $\mathrm{D}$ deficiency and consequent calcium disorders can be one of the reasons for the late eruption of teeth, which is common due to urban life and not receiving the right amount of vitamin D. ${ }^{(13,14)}$ According to a study by Holman and Yamaguchi, the eruption time of mandibular deciduous anterior teeth in children with moderate malnutrition is $13 \%$ to $15 \%$ delayed compared to well-nourished children, and 26$29 \%$ (two months) delay is observed in severely malnourished children compared with well-nourished children. ${ }^{(8)}$ The researchers also reported that one of the factors affecting the difference in eruption time in different populations is how infants are breastfed or formula-fed. The effect of breastfeeding on eruption time may be related to insufficient vitamin D in mothers. ${ }^{(8,9)}$ About $80 \%$ of Iranian pregnant women are deficient in vitamin $\mathrm{D}$, and there is a significant relationship between vitamin $\mathrm{D}$ deficiency in mothers and infants. ${ }^{(5,6,9)}$ A study conducted on children aged 1 to 10 years in Tehran shows that $51 \%$ of these children have serum levels of vitamin D below the optimum level. ${ }^{(15)}$ It seems that monitoring the eruption age of the first deciduous tooth and the level of serum vitamin D can be an indicator to prevent further problems associated with vitamin $\mathrm{D}$ deficiency, such as enamel hypoplasia and caries, as well as systemic problems, including rickettsia, which begins long before the onset of clinical symptoms. ${ }^{(12,14,16-19)}$ Due to the lack of sufficient studies in this regard, this study aimed to investigate the relationship of serum vitamin $\mathrm{D}$ and calcium levels with the eruption of the first deciduous tooth in infants in Tehran.

\section{Materials and Methods}

The present study was performed by a casecontrol method and after receiving the ethics code number of IR.IAU.DENTAL.REC.1395,6 from the School of Dentistry of Islamic Azad University of Medical Sciences, Tehran, Iran. After complete explanations for the parents and receiving written consent, the information form was completed by reviewing the child's medical record and direct questions from the parents.
Study participants were selected from referrals to a hospital in the center of Tehran (whose clients were from all parts of the city) and were studied for 1.5 years. The sample size was calculated to be 122 subjects (61 in each group) based on the results of the $G$ power software, $\alpha=0.05$, and Power $=80 \%$.

The determination of the normal age of eruption in this study was based on a study by Mahmoodian et al. ${ }^{(16)}$ The mean age of the eruption of the mandibular incisors in children in Tehran has been determined to be $7.88 \pm 2.40$ months. (16) Therefore, children were divided into two groups of A: normal time of eruption of the first deciduous incisor based on the average of Iranian society (less than 8 months) and B: the time of eruption of the first deciduous incisor at 8 months or more.

The inclusion criteria were as follows: Age of at least 4 months, Birth weight more than 2500 grams, Age of birth after 37 weeks, No history of a specific disease, anemia, hypothyroidism, underweight or overweight (based on age and growth curve), oral ulcers and scars, eruption problems, or family history of eruption delay, No history of pituitary insufficiency, hypothyroidism, hypoparathyroidism, gestational diabetes, or metabolic diseases during pregnancy, Regular maternal care based on the child's medical record in the examination center and questioning of mothers about pregnancy health. ${ }^{(20)}$

The children in the two groups were matched in terms of gender and the level of education of the mothers. The infants were included in the study from the age of 4 months until the report of the first eruption, and since the children were examined periodically on a monthly basis, the mothers were asked to report the first deciduous tooth eruption in the first subsequent examination. After determining the eruption time, the serum level of vitamin D (25-hydroxyvitamin D) was checked in the blood sample of each child that was routinely taken in the periodic care in the hospital. The level of vitamin D was measured using the VIDAS ${ }^{\circledR} 25 \mathrm{OH}$ Vitamin D Total kit (France) based on the enzyme-linked fluorescent assay (ELFA). The serum calcium level was assessed using the Pars Azmoon commercial kit (Tehran, Iran) based on the photometric method 
using ARSENAZO III. The serum levels of vitamin $\mathrm{D}$ and calcium were classified using the kit and recorded in the relevant form as follows:

\begin{tabular}{|c|c|c|}
\hline Calcium & \multicolumn{2}{|c|}{ Vitamin D } \\
\hline $8.5-10.8 \mathrm{mg} / \mathrm{dl}$ & $20<\mathrm{ng} / \mathrm{ml}$ & Deficient \\
\hline Deficient $>8.5$ & $\begin{array}{l}20-30 \mathrm{ng} / \mathrm{ml} \\
30-100 \mathrm{ng} / \mathrm{ml} \\
100>\mathrm{ng} / \mathrm{ml}\end{array}$ & $\begin{array}{c}\text { Inadequate } \\
\text { Adequate } \\
\text { Potentially }\end{array}$ \\
\hline
\end{tabular}

Statistical analysis:

Appropriate statistical tables and indicators, such as mean, have been used in describing the data. Student's t-test and analysis of variance (ANOVA) have been used for data analysis. Chi-square test (likelihood ratio) was used to analyze the data with a nominal scale. One-way ANOVA was used to evaluate the qualitative relationship while linear models were used for the combined study. The software used in this study was the SPSS (version18, Chicago, IL, USA), and the significance level of the tests was less than $5 \%$ (in the results, values less than $5 \%$ are marked with "*”, and values less than $1 \%$ are marked with “**”).

\section{Results}

Participants in this study were 61 subjects in each group, including 36 boys (59\%) and 25 girls $(41 \%)$. There was no statistically significant difference between the two groups in terms of maternal education $(\mathrm{P}=1.0)$, nutrition during infancy $(\mathrm{P}=0.41)$, and vitamin $\mathrm{A}+\mathrm{D}$ supplementation $(\mathrm{P}=0.31)$. The minimum and maximum eruption ages were 5 and 18 months, respectively. All erupted teeth were mandibular anterior incisors. The relationship between eruption age and demographic and nutritional characteristics of children in both groups is presented in Tables 1 and 2.

In neither group, there was a significant relationship between gender, maternal education, $\mathrm{A}+\mathrm{D}$ supplementation, and nutrition with the age of first deciduous tooth eruption. The relationship between mean serum levels of vitamin $D$ and calcium and the eruption time of the first mandibular deciduous incisor is summarized in Table 3.

The results of this table show that in terms of serum levels of vitamin D and calcium, there was no significant relationship between the two groups with eruption later than 8 months and sooner than 8 months.

Table 1. Comparison of eruption age based on demographic and nutritional variables of infants in group A with eruption age below 8 months

\begin{tabular}{|c|c|c|c|c|}
\hline & Number (\%) & & $\begin{array}{l}\text { Eruption } \\
\text { age }\end{array}$ & Probability \\
\hline Gender & $\begin{array}{l}25(41) \\
36(59)\end{array}$ & $\begin{array}{l}\text { Boy } \\
\text { Girl }\end{array}$ & $\begin{array}{l}7.1 \pm 1.1 \\
7.1 \pm 0.9\end{array}$ & $\mathrm{P}=0.94$ \\
\hline $\begin{array}{l}\text { Mother' } \\
\text { S } \\
\text { educati } \\
\text { on }\end{array}$ & $\begin{array}{l}18(29.5) \\
43(70.5)\end{array}$ & $\begin{array}{c}\text { None- } \\
\text { academic } \\
\text { Academic }\end{array}$ & $\begin{array}{l}7.2 \pm 0.9 \\
7.1 \pm 1.0\end{array}$ & $\mathrm{P}=0.85$ \\
\hline $\begin{array}{c}\mathrm{A}+\mathrm{D} \\
\text { supple } \\
\text { ment }\end{array}$ & $\begin{array}{c}54(88.5) \\
7(11.5)\end{array}$ & $\begin{array}{l}\text { No } \\
\text { Yes }\end{array}$ & $\begin{array}{l}7.2 \pm 0.9 \\
6.3 \pm 1.5\end{array}$ & $\mathrm{P}=0.14$ \\
\hline $\begin{array}{c}\text { Nutritio } \\
n\end{array}$ & $\begin{array}{c}35(57.4) \\
7(11.5) \\
19(31.1)\end{array}$ & $\begin{array}{l}\text { Breast milk } \\
\text { Formula } \\
\text { Both }\end{array}$ & $\begin{array}{l}7.0 \pm 1.1 \\
7.3 \pm 0.7 \\
7.4 \pm 0.6\end{array}$ & $\mathrm{P}=0.31$ \\
\hline
\end{tabular}

At the same time, serum levels of vitamin D and calcium in both groups were in the normal range (vitamin D between 30 and $100 \mathrm{ng} / \mathrm{ml}$ and calcium between 8.5 and $10.8 \mathrm{mg} / \mathrm{dl}$ ).

Table 2. Comparison of eruption age based on demographic and nutritional variables of infants in group B with eruption age of 8 months and older

\begin{tabular}{ccccc} 
group B with eruption age of 8 months and older \\
\hline & $\begin{array}{c}\text { Number } \\
(\%)\end{array}$ & & $\begin{array}{c}\text { Eruption } \\
\text { age }\end{array}$ & Probability \\
\hline Gender & $25(41)$ & Boy & $10.0 \pm 1.1$ & $\mathrm{t}=0.87$ \\
& $36(59)$ & Girl & $9.8 \pm 0.9$ & $\mathrm{P}=0.38$ \\
Mother's & $18(29.5)$ & None- & $9.7 \pm 1.0$ & $\mathrm{t}=1.07$ \\
education & $43(70.5)$ & $\begin{array}{c}\text { academic } \\
\text { Academic }\end{array}$ & $10.0 \pm 1.0$ & $\mathrm{P}=0.28$ \\
& & Academ & \\
A+D & $12(19.7)$ & No & $10.0 \pm 1.1$ & $\mathrm{t}=1.36$ \\
supplement & $49(80.3)$ & Yes & $9.2 \pm 0.5$ & $\mathrm{P}=0.17$ \\
& & & & \\
Nutrition & $39(64)$ & Breast & $9.9 \pm 0.9$ & $\mathrm{~F}=0.59$ \\
& $7(11.5)$ & milk & $9.6 \pm 1.0$ & $\mathrm{P}=0.55$ \\
& $15(24.5)$ & Formula & $10.1 \pm 1.3$ & \\
& \multicolumn{5}{c}{ Both } \\
\hline
\end{tabular}

The results of one-way ANOVA, which was performed to evaluate the qualitative effect of vitamin D levels (adequate, inadequate, deficient, toxic) on tooth eruption age, showed a significant relationship between different levels of vitamin $\mathrm{D}$ and tooth eruption age. In addition, $37.7 \%$ of children with tooth eruption age of 8 months or less and $39.3 \%$ of children with eruption age more than 8 months had less than optimal vitamin D ( $>0.05$; Table 4). Table 5 compares the regular or non-regular intake of vitamin supple- 
ments in infants who were breastfed, formulafed, or combination-fed. Based on the results, no significant difference was observed in terms of receiving or not receiving supplements and feeding style in the two groups with eruption times of 8 months and less and over 8 months.

Table 3. Evaluation of mean (standard deviation) of vitamin $D$ and calcium levels in the two groups with deciduous mandibular incisor eruption age of 8 months or less and over 8 months

\begin{tabular}{lccc}
\hline & $<8$ months & $\geq 8$ months & Probability \\
& & & \\
Vitamin D level & $40.0 \pm 21.5$ & $38.1 \pm 24.1$ & $\mathrm{P}=0.63$ \\
Calcium level & $9.92 \pm 0.57$ & $10.03 \pm 0.55$ & $\mathrm{P}=0.28$ \\
$\begin{array}{c}\text { Eruption time } \\
\text { (month) }\end{array}$ & $9.90 \pm 0.1$ & $7.1 \pm 0.9$ & $\mathrm{P}=0.0001 * *$ \\
\hline
\end{tabular}

Table 4. Qualitative comparison of vitamin D levels between the normal eruption age of deciduous mandibular incisors and higher than normal eruption age

\begin{tabular}{lccc}
\hline Eruption age & $<8$ months & $\geq 8$ months & \\
\hline $\begin{array}{c}\text { Vitamin } \mathrm{D} \\
\text { level }\end{array}$ & $\begin{array}{c}\text { Number } \\
(\%)\end{array}$ & $\begin{array}{c}\text { Number } \\
(\%)\end{array}$ & Probability \\
Deficient & $8(13.1)$ & $10(16.4)$ & \\
Inadequate & $16(26.2)$ & $13(21.3)$ & \\
Adequate & $34(55.7)$ & $37(60.7)$ & \\
Toxic & $3(4.9)$ & $1(1.6)$ & \\
& & &
\end{tabular}

Table 5. Comparison of vitamin A+D supplementation between the breastfed group and other groups based on tooth eruption age

\begin{tabular}{llllll}
\hline $\begin{array}{l}\text { Eruption } \\
\text { age }\end{array}$ & Supplement & $\begin{array}{l}\text { Breast } \\
\text { milk } \\
\text { Frequency }\end{array}$ & $\begin{array}{l}\text { Formula } \\
\text { Frequency }\end{array}$ & $\begin{array}{l}\text { Combination } \\
\text { Frequency }\end{array}$ & Probability \\
\hline Below 8 & Yes & 32 & 6 & 16 & $\mathrm{P}=0.71$ \\
months & No & 3 & 1 & 3 & \\
Over 8 & Yes & 29 & 7 & 13 & $\mathrm{P}=0.11$ \\
months & No & 10 & 0 & 2 & \\
Total & Yes & 61 & 13 & 29 & $\mathrm{P}=0.56$ \\
& No & 13 & 1 & 5 & \\
\hline
\end{tabular}

\section{Discussion}

According to the results of the present study, no significant difference was observed in the serum level of vitamin D in children whose first deciduous tooth erupted at the age of 8 months or less compared to children whose eruption age was more than 8 months. The choice of the age of 8 months is based on the evaluation of the mean age of eruption of the first deciduous tooth in Tehran children, which was assessed by Mahmoodian et al to be $7.88 \pm 2.40$ months. $^{(16)}$ Given that eruption delay means increasing two standard deviations to the average eruption time ${ }^{(20)}$ this rate in the study population will be equal to 12.7 months. By examining 400 children aged 4 to 18 months to evaluate the inclusion criteria, eruption later than 12 months was observed in a handful of children. Finally, considering the criteria for participating in the study, only four children $(3.3 \%)$ in each age group had eruption age of 12 to 13 months, and therefore, the mean age of eruption was the basis for comparing the two groups. In the current study, the mean eruption age was 7.1 months (28.4 weeks) in the first group and 9.9 months (39.6 weeks) in the second group. According to the classic study by Speidel and Stearns (1940), the age of eruption of the first deciduous tooth in children receiving 135 to 270 units of vitamin D per day was 28.29 weeks, which is consistent with the age of eruption in children in the first group of our study. The mean serum level of vitamin $D$ in these children was $38.1 \mathrm{ng} / \mathrm{ml}$, which is equivalent to 152 units of vitamin D. In infants with eruption later than 8 months, the serum level of vitamin D was $40 \mathrm{ng} / \mathrm{ml}$ equivalent to 160 units, which was numerically higher than that of the first group, although this difference was not statistically significant. These results are in line with the findings of the study by Speidel and Stearns, which showed that children who received 300-400 units of vitamin D daily had the fastest eruption time (24.6 weeks) compared to lower or higher doses (1800 units). (17) According to the national guidelines, daily vitamin $A+D$ supplementation containing 400 units of vitamin $D$ is routinely recommended for infants from 3-5 days of birth to the end of 
24 months, which is equivalent to 10 micrograms of vitamin D daily. Despite this, some children in the study either received vitamin supplements irregularly or did not take them at all. Examining the time of eruption of the first deciduous tooth in children who were breastfed, formula-fed, or combination-fed did not show a statistically significant relationship with vitamin D supplementation. Serum vitamin D levels in $60.7 \%$ of children with eruption age of 8 months or less and $55.7 \%$ of children with eruption time later than 8 months were adequate, ranging from 30 to $100 \mathrm{ng} / \mathrm{ml}$. At the same time, three children with eruption time later than 8 months had toxic levels of vitamin D. According to a study by Kaabneh et al in Jordan (2016), adding vitamin $\mathrm{D}$ to the diet has no effect on the eruption time of deciduous teeth in preterm infants. ${ }^{(21)}$ One possible reason for the ineffectiveness of vitamin D levels on eruption time in infants and neonates is the high level of serum calcium due to breastfeeding in this age group. Adequate intake of either calcium or vitamin D can compensate for another's reduction, and clinical signs can lead to nutritional rickets only in cases of severe deficiency of calcium or vitamin $\mathrm{D}$, either during pregnancy or at birth, when the eruption rate is high. ${ }^{(22)}$ According to a prospective cohort study by Delgado et al, vitamin $\mathrm{D}$ administration to preterm infants did not affect the eruption or maturation of deciduous teeth but was associated with accelerated permanent tooth maturation, which is consistent with the results of our study. ${ }^{(23)}$ In a prospective cohort study, Dhamo et al found that maternal vitamin D deficiency during pregnancy was associated with delayed development and eruption of permanent teeth. ${ }^{(22)}$ In a study by Jairam et al, delayed eruption of deciduous teeth was reported with vitamin D deficiency. In the mentioned study, vitamin deficiency was defined based on a serum level of $11.65 \mathrm{ng} / \mathrm{ml}$, and the delayed eruption was considered as no tooth eruption between the ages of 12 and 15 months $^{(14)}$

According to a study by Holman and Yamaguchi, the eruption time of mandibular deciduous incisors in children with poor or moderate nutritional status, compared to children with good nutrition, was delayed by two and one months, respectively. ${ }^{(8)}$ Lack of nutritional factors such as protein and calories affects tooth eruption.
Considering that according to the growthmonitoring curve, eligible children were in the normal range, and overweight or underweight children were not included in the study, the effects of malnutrition due to calorie deficiency were eliminated. The effect of protein needs further investigation; however, none of the infants and children showed clinical signs of severe protein deficiency. ${ }^{(8,12,23)}$

One of the limitations of the present study was the limited number of children whose eruption time was more than two standard deviations from the average (eruption age of 12.7 months). In this study, more than 400 children were evaluated for inclusion in the study, but due to the small number of cases with eruption age over 12 months, it was not possible to assess a sufficient number of these children. Among the limitations of the research, we can mention the high standard deviation in the amount of vitamin D in both groups, which is another interfering factor that should be examined and standardized.

It is recommended to study vitamin D levels in children with eruption age over 12 months in a wider study, individually or in several centers in different parts of the country. Examining the relationship between the time of eruption of permanent teeth and serum level of vitamin $D$ is another issue that can have practical results.

\section{Conclusion}

Based on the results of the present study, no significant relationship was found between serum vitamin $\mathrm{D}$ and calcium levels and the average eruption age of children in Tehran. Given that changes in the latitude, amount of sunlight, and diet are different in different parts of the country, conducting similar studies on the eruption of deciduous or permanent teeth can help explain this relationship.

\section{References}

1.Poureslami H, Asl Aminabadi N, Sighari Deljavan A, Erfanparast L, Sohrabi A, Jamali Z, et al. Does Timing of Eruption in First Primary Tooth Correlate with that of First Permanent Tooth? A 9-years Cohort Study. J Dent Res Dent Clin Dent Prospects. 2015;9(2):79-85.

2. Wu H, Chen T, Ma Q, Xu X, Xie K, Chen Y. Associations of maternal, perinatal and postnatal factors with the eruption timing of the first primary tooth. Sci Rep. 2019;9(1):2645. 
3.Soliman NL, El-Zainy MA, Hassan RM, Aly RM. Timing of deciduous teeth emergence in Egyptian children. East Mediterr Health J. 2011;17(11):875-81.

4.Hughes TE, Bockmann MR, Seow K, Gotjamanos T, Gully N, Richards LC, et al. Strong Genetic Control of Emergence of Human Primary Incisors. J Dent Res. 2007;86(12):11605.

5.Naik P, Faridi MMA, Batra P, Madhu SV. Oral Supplementation of Parturient Mothers with Vitamin D and Its Effect on 25OHD Status of Exclusively Breastfed Infants at 6 Months of Age: A Double-Blind Randomized Placebo Controlled Trial. Breastfeed Med. 2017;12(10):621-8.

6.Maghbooli Z, Hossein-Nezhad A, Shafaei AR, Karimi F, Madani FS, Larijani B. Vitamin D status in mothers and their newborns in Iran. BMC Pregnancy Childbirth. 2007;7:1.

7.Trivedi M, Faridi MMA, Aggarwal A, Madhu SV, Malhotra RK. Oral Vitamin D Supplementation to Mothers During Lactation-Effect of 25(OH)D Concentration on Exclusively Breastfed Infants at 6 Months of Age: A Randomized Double-Blind Placebo-Controlled Trial. Breastfeed Med. 2020 Apr;15(4):237-245.

8.Holman DJ, Yamaguchi K. Longitudinal analysis of deciduous tooth emergence: IV. Covariate effects in Japanese children. Am J Phys Anthropol. 2005;126(3):352-8.

9.Emdadi R, Chaichian S, Mahboubi M, Moradi Y, Akhlaghdoust M, Basharkhah A. Prevalence of Vitamin D Deficiency Among Women of Reproductive Age: A Multi Centric Study in Tehran. Shiraz E-Med J. 2016;17(11):e40745.

10. Pettifor JM. Nutritional rickets: deficiency of vitamin D, calcium, or both? Am J Clin Nutr. 2004;80(6):1725S-9S.

11. Saggese G, Vierucci F, Prodam F, Cardinale F, Cetin I, Chiappini E, et al. Vitamin D in pediatric age: consensus of the Italian Pediatric Society and the Italian Society of Preventive and Social Pediatrics, jointly with the Italian Federation of Pediatricians. Italian J Pediatr. 2018;44(1):51.

12. Högler W. Complications of vitamin D deficiency from the foetus to the infant: One cause, one prevention, but who's responsibility? Best Pract Res Clin Endocrinol Metab. 2015;29(3):385-98.

13. Heaney RP, Davies KM, Chen TC, Holick MF, BargerLux MJ. Human serum 25-hydroxycholecalciferol response to extended oral dosing with cholecalciferol. Am J Clin Nutr. 2003 Jan;77(1):204-10.

14. Jairam L, Konde S, Raj N, Kumar N. Vitamin D deficiency as an etiological factor in delayed eruption of primary teeth: A cross-sectional study. J Indian Soc Pedod Prev Dent. 2020;38(3):211-5.

15. Babaniamansour S, Hematyar M, Babaniamansour P, Babaniamansour A, Aliniagerdroudbari E. The Prevalence of Vitamin D Deficiency Among One to Six Year Old Children of Tehran, Iran. J Kermanshah Univ Med Sci. 2019;23(4):e95185.

16. Mahmoodian J, Ghandehari M, Khojani M. Longitudinal study of time and sequence of primary teeth eruption in children, residents in Tehran, from birth (2000-2002). J Islam Dent Assoc IRAN (JIDA). 2005;17(1):34-9.

17. Speidel TD, Stearns G. The relation of vitamin D intake to the age of the infant at the time of eruption of the first deciduous incisor. J Pediatr. 1940;17(4):50611 .
18. Kim IJ, Lee HS, Ju HJ, Na JY, Oh HW. A cross-sectional study on the association between vitamin D levels and caries in the permanent dentition of Korean children. BMC Oral Health. 2018;18(1):43.

19. Jartti T, Liimatainen U, Xepapadaki P, Vahlberg T, Bachert C, Finotto S, et al. Clinical correlates of rhinovirus infection in preschool asthma. Allergy. $2021 \mathrm{Jan} ; 76(1): 247-254$. 20. Suri L, Gagari E, Vastardis H. Delayed tooth eruption: pathogenesis, diagnosis, and treatment. A literature review. Am J Orthod Dentofacial Orthop. 2004;126(4):432-45.

21. Kaabneh MAF, Salama G, Sunna N. Impact of Oral Vitamin D Supplementation on First Tooth Eruption of Jordanian Premature Infants. J Royal Med Serv. 2016;23:11-9. 22. Dhamo B, Miliku K, Voortman T, Tiemeier H, Jaddoe VW, Wolvius EB, et al. The Associations of Maternal and Neonatal Vitamin D with Dental Development in Childhood. Curr Dev Nutr. 2019 Mar 7;3(4):nzy100.

23. Delgado H, Habicht JP, Yarbrough C, Lechtig A, Martorell R, Malina RM, et al. Nutritional status and the timing of deciduous tooth eruption. Am J Clin Nutr. 1975;28(3):21624.

\section{Cite this paper as}

Noori nezhad A, salem K, Zamanian M, Aghaei

S. Comparison of Serum Vitamin D and Calcium Levels Between Children with Longer Than Normal Eruption Time of First Deciduous Tooth and Control Group. J Res Dent Maxillofac Sci.2021;6 (3):25-30 